\title{
Moderate to severe maternal anaemia in pregnancy and its impact on perinatal outcome in tertiary care hospital
}

\author{
Ashram Khatana ${ }^{1}$, Suniti Verma ${ }^{1 *}$, Ram Narain Sehra ${ }^{2}$, Kanti Yadav ${ }^{3}$ \\ ${ }^{1}$ Department of Obstetrics and Gynecology, ${ }^{2}$ Department of Paediatric Medicine, SMS Medical College, Jaipur, \\ Rajasthan, India \\ ${ }^{3}$ Department of Obstetrics and Gynecology, JLN Medical College, Ajmer, Rajasthan, India \\ Received: 26 January 2020 \\ Accepted: 28 February 2020 \\ *Correspondence: \\ Dr. Suniti Verma, \\ E-mail:dr.suniti.verma@gmail.com \\ Copyright: (C) the author(s), publisher and licensee Medip Academy. This is an open-access article distributed under \\ the terms of the Creative Commons Attribution Non-Commercial License, which permits unrestricted non-commercial \\ use, distribution, and reproduction in any medium, provided the original work is properly cited.
}

\begin{abstract}
Background: Anaemia is the commonest medical disorder in pregnancy and has a varied prevalence, etiology and degree of severity in different populations. The purpose of this study was to evaluate the prevalence of maternal anaemia in pregnancy and its impact on perinatal outcome.

Methods: This was a prospective observational study conducted in department of obstetrics and gynecology JLN Hospital Ajmer, Rajasthan, India from October 2015 to December 2016. Total 325 pregnant women were included in the study who fulfilled the inclusion criteria and found to have moderate to severe anaemia.

Results: Prevalence of anaemia in pregnancy was $80 \%$ in present study. Perinatal mortality was $13.3 \%$ in moderate anaemia and in severe anaemia $42 \%$. In present study maximum $56 \%$ of cases were in the age group of 20-25 years, and maximum number of cases were primigravida (33.84\%). Out of 225 cases of moderate anaemia only 50 cases $(22.22 \%)$ had antenatal check-up once or twice. Out of 225 cases of moderate anaemia, $66.66 \%$ cases were rural and $33.33 \%$ cases were of urban group. Fetal outcome in present study was in form of $49.23 \%$ premature birth with $33.12 \%$ perinatal mortality.

Conclusions: Maternal anaemia in pregnancy is associated with illiteracy, low socioeconomic status, multiparity, inadequate antenatal care and rural geographic area. Severe anaemia was associated with high perinatal mortality.
\end{abstract}

Keywords: Haemoglobin, Maternal anaemia, Perinatal outcome, Severe anaemia

\section{INTRODUCTION}

Anaemia is the commonest medical disorder in pregnancy and has a varied prevalence, etiology and degree of severity in different populations being more common in non-industrial countries. ${ }^{1}$ World Health Organization definition for diagnosis of anaemia in pregnancy is a haemoglobin concentration of less than 11 $\mathrm{g} / \mathrm{dl}(7.5 \mathrm{mmol} / \mathrm{l})$ and a hematocrit of less than 0.33 . $^{2}$ The World Health Organization uses the following haemoglobin cut offs to define anaemia in pregnant women. 90 to $109 \mathrm{~g} / 1$ for mild anaemia, 70 to $89 \mathrm{~g} / 1$ for moderate anaemia and lower than $70 \mathrm{~g} / 1$ for severe anaemia. In India, more than $90 \%$ of anaemia cases are estimated to be due to iron deficiency because high iron requirement during pregnancy are not easily fulfilled by dietary intake especially when iron bio-availability is poor. ${ }^{3}$ Estimates from the World Health Organization report that from $35 \%$ to $75 \%$ (56\% on an average) of pregnant women in developing countries and $18 \%$ of women from industrialized countries are anaemic. ${ }^{4}$ The prevalence of anaemia is high in central Asia and reported as $61-91 \%$ in India. 5,6

Maternal anaemia in pregnancy is commonly considered as risk factor for poor pregnancy outcome and can 
threaten the life of mother and fetus. ${ }^{7}$ Severe maternal anaemia has poor outcome of neonates in the form of low birth weight, prematurity, IUGR, IUD and birth asphyxia. ${ }^{8}$ However, the extent to which the maternal haemoglobin concentration affects the fetal outcome is still uncertain. Some studies have shown a strong association between low haemoglobin level before delivery and an adverse outcome, while other studies have not shown significant association. Thus, the purpose of this study was to evaluate the prevalence of maternal anaemia in pregnancy and its impact on perinatal outcome.

\section{METHODS}

This was a hospital based prospective observational study conducted in department of obstetrics and gynecology JLN Hospital Ajmer, Rajasthan, India from October 2015 to December 2016. Minimum sample size of 261 was calculated at $95 \%$ confidence interval, $80 \%$ study power, alfa error $0.05 \%$ with occurrence of perinatal mortality $22.2 \%$ in moderate and severe maternal anaemia as per reference article. ${ }^{9}$

Study included all the women with gestational age between 20-41 weeks who admitted in delivery room with anaemia and singleton pregnancy. Women with multiple pregnancy, thalassemia minor, history of addiction, TORCH and malaria infection, past history of preterm delivery, complications, or medical illness except anaemia, were excluded from the study. 1000 pregnant women were admitted in labour room had undergone haemoglobin estimation and routine investigations. Total 325 pregnant women were included in study who fulfilled the inclusion criteria and found to have moderate to severe anaemia. Moderate anaemia had Hb 7-8.9 gm\% and severe anaemia had $\mathrm{Hb}<7 \mathrm{gm} \%$.

A predesigned proforma was used to obtain relevant information's. All cases were studied in full details regarding literacy, age residence, education, socioeconomic status, parity, interval between conception, history of abortions and outcome of previous pregnancy. Patient with moderate to severe anaemia were investigated for haematocrit value, peripheral blood film, serum iron, total iron binding capacity, stool examination, complete urine examination. Wherever required, special investigations such as $\mathrm{x}$-ray chest, ECG and USG abdomen were done. Perinatal outcome was judged by detailed neonatal examination at birth and during hospital stay. Neonatal examination included weight, length, gestational age, assessment, intra uterine growth retardation, still birth and intra uterine death assessment.

Modified Kuppuswami's classification was used to classify in upper, middle and lower socioeconomic status. The study was conducted according to the guidelines and approved by institutional research review board. Written informed consent was taken from all patients at the time of enrolment.

\section{Statistical analysis}

Information of cases under study was arranged in systemic manner in MS-excel sheet. Appropriate statistical analysis was done using frequencies, cross tabulation and percentages. Conclusion was made as per the respective level of significance.

\section{RESULTS}

Out of 1000 cases admitted in labour room 325 cases had moderate to severe anaemia and they were studied to find out the prevalence of anaemia and perinatal outcome.

Table 1: Prevalence of anaemia in pregnancy.

\begin{tabular}{|lll|}
\hline Degree of anaemia & Number of cases & Percentage \\
\hline No anaemia & 200 & $20 \%$ \\
\hline Mild & 475 & $47.5 \%$ \\
\hline Moderate & 225 & $22.5 \%$ \\
\hline Severe & 100 & $10 \%$ \\
\hline Total & 1000 & $100 \%$ \\
\hline
\end{tabular}

\section{Prevalence}

In the present study 475 patients were found to have mild anaemia (Hb $9-11 \%$ ) which accounted for $47.5 \%$ of the total cases observed. $22.5 \%$ had moderate anaemia ( $\mathrm{Hb} 7$ $8.9 \%)$. Severe anaemia $(\mathrm{Hb}<7 \mathrm{gm} \%)$ was observed in $10 \%$ of cases. So, overall prevalence of anaemia in pregnancy was $80 \%$ in present study (Table 1).

Table 2: Degree of anaemia and perinatal mortality.

\begin{tabular}{|l|l|l|}
\hline $\begin{array}{l}\text { Degree of } \\
\text { anaemia }\end{array}$ & $\begin{array}{l}\text { No. of cases } \\
(\%)\end{array}$ & $\begin{array}{l}\text { Perinatal mortality } \\
\text { No. of cases (\%) }\end{array}$ \\
\hline Moderate & $225(22.5 \%)$ & $30(13.3 \%)$ \\
\hline Severe & $100(10 \%)$ & $42(42 \%)$ \\
\hline
\end{tabular}

\section{Degree of anaemia}

Perinatal mortality was $13.3 \%$ in moderate anaemia and very high in cases of severe anaemia $42 \%$ (Table 2 ).

Age

In present study maximum $56 \%$ of cases were in the age group of $20-25$ years. $30.76 \%$ cases were in age group $26-30$ years and $8.5 \%$ cases were above 30 years of age. Only $4.6 \%$ of cases were below 20 years of age. Perinatal mortality was maximum between 20-30 years of age (Table 3).

\section{Parity}

In the present study maximum number of cases were primigravida i.e. $33.84 \%, 25.53 \%$ cases were $\mathrm{P} 1$ and $24.00 \%$ cases were P2. Highest perinatal mortality was found in P6 or more; $75 \%$ (Table 3). 
Table 3: Different factors of pregnant women affecting perinatal mortality.

\begin{tabular}{|c|c|c|c|}
\hline \multirow[t]{2}{*}{ Variables } & \multirow{2}{*}{\multicolumn{2}{|c|}{ No. of cases $(\%)$}} & $\begin{array}{l}\text { Perinatal } \\
\text { mortality }\end{array}$ \\
\hline & & & No. of cases $(\%)$ \\
\hline \multicolumn{4}{|l|}{ Age (years) } \\
\hline$<20$ & \multicolumn{2}{|c|}{$15(4.6 \%)$} & $4(1.23 \%)$ \\
\hline $20-25$ & \multicolumn{2}{|c|}{$182(56 \%)$} & $29(8.92 \%)$ \\
\hline $26-30$ & \multicolumn{2}{|c|}{$100(30.76 \%)$} & $29(8.92 \%)$ \\
\hline$>31$ & \multicolumn{2}{|c|}{$28(8.5 \%)$} & $10(3.07 \%)$ \\
\hline \multicolumn{4}{|l|}{ Parity } \\
\hline $\mathrm{P} 0-\mathrm{P} 2$ & \multicolumn{2}{|c|}{$269(82.76 \%)$} & $50(15.38 \%)$ \\
\hline P3-P5 & \multicolumn{2}{|c|}{$52(16.0 \%)$} & $19(5.84 \%)$ \\
\hline$>$ P6 & \multicolumn{2}{|c|}{$4(1.23 \%)$} & $3(0.92 \%)$ \\
\hline \multicolumn{4}{|c|}{ Antenatal visit } \\
\hline \multirow{2}{*}{$\begin{array}{l}\text { Moderate } \\
\text { Anaemia }\end{array}$} & Yes & $50(22.22 \%)$ & $3(6 \%)$ \\
\hline & No & $175(77.77 \%)$ & $30(17.14 \%)$ \\
\hline \multirow{2}{*}{$\begin{array}{l}\text { Severe } \\
\text { Anaemia }\end{array}$} & Yes & $10(10 \%)$ & $2(20 \%)$ \\
\hline & No & $90(90 \%)$ & $37(41.11 \%)$ \\
\hline \multicolumn{4}{|l|}{ Residence } \\
\hline \multirow{2}{*}{$\begin{array}{l}\text { Moderate } \\
\text { anaemia }\end{array}$} & Rural & $150(66.66 \%)$ & $22(14.66 \%)$ \\
\hline & Urban & $75(33.33 \%)$ & $8(10.66 \%)$ \\
\hline \multirow{2}{*}{$\begin{array}{l}\text { Severe } \\
\text { anaemia }\end{array}$} & Rural & $75(75 \%)$ & $33(44 \%)$ \\
\hline & Urban & $25(25 \%)$ & $9(36 \%)$ \\
\hline \multicolumn{4}{|c|}{ Socioeconomic status } \\
\hline Low & \multicolumn{2}{|c|}{$200(61.53 \%)$} & $54(27 \%)$ \\
\hline $\begin{array}{l}\text { Lower } \\
\text { middle }\end{array}$ & \multicolumn{2}{|c|}{$100(30.76 \%)$} & $16(16 \%)$ \\
\hline Upper middl $\epsilon$ & \multicolumn{2}{|c|}{$25(7.69 \%)$} & $2(8 \%)$ \\
\hline \multicolumn{4}{|c|}{ Educational status } \\
\hline Illiterate & \multicolumn{2}{|c|}{$160(49.23 \%)$} & $48(30 \%)$ \\
\hline Primary & \multicolumn{2}{|c|}{$100(30.76 \%)$} & $20(20 \%)$ \\
\hline Middle & \multicolumn{2}{|c|}{$40(12.30 \%)$} & $3(7.5 \%)$ \\
\hline $\begin{array}{l}\text { High school } \\
\text { to graduation }\end{array}$ & \multicolumn{2}{|c|}{$25(7.69 \%)$} & $1(4 \%)$ \\
\hline
\end{tabular}

\section{Antenatal check-up}

Out of 225 cases of moderate anaemia only 50 cases $(22.22 \%)$ had antenatal check-up once or twice. 175 $(77.77 \%)$ cases had no previous antenatal check-up. Out of 50 cases of moderate anaemia who had antenatal visits perinatal mortality was $6 \%$ while in 175 cases who had no antenatal visit perinatal mortality was $17.14 \%$. Out of 100 cases of severe anaemia, 90\% had no previous antenatal visit and $10 \%$ had one or two antenatal visit. Perinatal mortality was $20 \%$ in cases who had previous antenatal visit and $41.11 \%$ in cases who had no previous antenatal visit (Table 3 ).

\section{Geographic distribution}

Out of 225 cases of moderate anaemia, $66.66 \%$ cases were rural and $33.33 \%$ cases were of urban group. Perinatal mortality was $14.66 \%$ in rural group and $10.66 \%$ in urban group. In severe anaemia out of 100 cases $75 \%$ were rural and $25 \%$ were urban. Perinatal mortality was $44 \%$ in rural and $36 \%$ in urban population (Table 3).

\section{Socioeconomic status}

Out of 325 cases of anaemia $61.53 \%$ cases were of low socioeconomic class, $30.76 \%$ cases were of lower middle and only $7.69 \%$ cases were of upper middle class. Perinatal mortality was $27 \%$ in low class, $16 \%$ in lower middle class and $12 \%$ in upper middle class (Table 3 ).

\section{Educational status}

Out of 325 cases of anaemia $49.23 \%$ cases were illiterate, $30.76 \%$ cases had primary education. $12.30 \%$ cases had education up to VIII class and $7.69 \%$ cases had education up to graduation. Perinatal mortality was $30 \%$ in illiterate group as compared to $4 \%$ in literate or educated group (Table 3).

\section{Type of anaemia}

Out of 325 cases of moderate and severe anaemia peripheral blood film showed microcytic hypochromic anaemia in 180 cases $(55.38 \%)$, dimorphic anaemia in 80 cases $(24.61 \%)$, normocytic normochromic anaemia in 35 cases $(10.76 \%)$, normocytic hypochromic anaemia in 27 cases $(8.30 \%)$ and haemolytic anaemia in 3 cases $(0.92 \%)$. Perinatal mortality was $17.5 \%$ in dimorphic, $25.55 \%$ in microcytic hypochromic, $17.14 \%$ in normocytic normochromic and $22.22 \%$ in normocytic hypochromic anaemia (Table 4).

Table 4: Perinatal mortality in association with type of anaemia.

\begin{tabular}{|lll|}
\hline Type of anaemia & $\begin{array}{l}\text { No. of cases } \\
(\%)\end{array}$ & $\begin{array}{l}\text { Perinatal } \\
\text { mortality }\end{array}$ \\
\hline $\begin{array}{l}\text { No. of cases } \\
\text { (\%) }\end{array}$ \\
\hline Dimorphic anaemia & $80(24.61 \%)$ & $14(17.5 \%)$ \\
\hline $\begin{array}{l}\text { Microcytic hypochromic } \\
\text { anaemia }\end{array}$ & $180(55.38 \%)$ & $46(25.55 \%)$ \\
\hline $\begin{array}{l}\text { Normocytic } \\
\text { normochromic anaemia }\end{array}$ & $35(10.76 \%)$ & $6(17.14 \%)$ \\
\hline $\begin{array}{l}\text { Normocytic hypochromic } \\
\text { anaemia }\end{array}$ & $27(8.30 \%)$ & $6(22.22 \%)$ \\
\hline Haemolytic anaemia & $3(0.92 \%)$ & $0(0 \%)$ \\
\hline
\end{tabular}

\section{Fetal outcome}

Fetal outcome in present study was in form of $49.23 \%$ premature (gestation age $<37$ weeks) birth with $33.12 \%$ perinatal mortality. There was $21.53 \%$ of mature babies with normal birth weight with $7.14 \%$ perinatal mortality and $29.23 \%$ of mature with low birth weight babies (weight $<2.5 \mathrm{~kg}$ ) with $14.73 \%$ perinatal mortality (Table 5). 
Table 5: Fetal outcome in anaemia patients.

\begin{tabular}{|lll|}
\hline New born baby & $\begin{array}{l}\text { No. of cases } \\
(\%)\end{array}$ & $\begin{array}{l}\text { Perinatal } \\
\text { mortality } \\
\text { No. of cases (\%) }\end{array}$ \\
\hline $\begin{array}{l}\text { Mature with normal } \\
\text { birth weight }\end{array}$ & $70(21.53 \%)$ & $5(7.14 \%)$ \\
\hline $\begin{array}{l}\text { Mature with low } \\
\text { birth weight }\end{array}$ & $95(29.23 \%)$ & $14(14.73 \%)$ \\
\hline Premature & $160(49.23 \%)$ & $53(33.12 \%)$ \\
\hline
\end{tabular}

\section{DISCUSSION}

\section{Prevalence}

In the present study mild anaemia accounted for $47.5 \%$ of the total cases, $22.5 \%$ had moderate anaemia and severe anaemia was observed in $10 \%$ of cases. So overall prevalence of anaemia in pregnancy was $80 \%$ in present study. Modok GC et al, observed prevalence of anaemia $(81.5 \%)$ and moderate to severe anaemia in $12 \%$ cases. $^{10}$ Nair $M$ et al, observed anaemia in $(34.9 \%)$ cases with moderate anaemia $32.8 \%$ and severe anaemia $2.1 \%{ }^{9} \mathrm{AL}$ Mehaisen L et al, observed anaemia in $(34.2 \%)$ case and moderate to severe anaemia $3 \%{ }^{11}$ Lokare PO et al, studied anaemia in $(87.2 \%)$ with moderate anaemia $54.5 \%$ and severe anaemia $7.9 \%{ }^{12}$ Agrawal $\mathrm{KN}$ et al, also studied slightly higher prevalence $(>90 \%) .{ }^{13}$ A high prevalence of anaemia in pregnant women is multifactorial in origin. Often these factors interact and amplify each other. The single most important cause for the wide spread anaemia is inadequate iron intake in diet and coupled with poor bioavailability of iron because of low amount of ascorbic acid.

\section{Degree of anaemia}

Perinatal mortality was $13.3 \%$ in moderate anaemia and $42 \%$ in cases of severe anaemia. Donade $U$ et al, found that incidence of perinatal death was $12.2 \%$ in moderate anaemia and $36 \%$ in severe anaemia which is comparable with this study. ${ }^{14}$ Nair $\mathrm{M}$ et al, observed perinatal mortality $22.2 \%$ including $3.1 \%$ in moderate anaemia and $19.1 \%$ in severe anaemia. DasGupta $\mathrm{S}$ et al, observed severe anaemia was responsible for $13 \%$ perinatal mortality. ${ }^{15}$

\section{Parity}

In the present study maximum number of cases were $\mathrm{p} 0$ (33.84\%), $25.53 \%$ cases were $\mathrm{p} 1$ and $24.00 \%$ cases were p2. Highest maternal and perinatal mortality was found in p6 or more; $75 \%$ each. Satyanarayan $M$ et al, reported $28 \%$ cases of anaemia in $2^{\text {nd }}$ and $3^{\text {rd }}$ gravida each, $16 \%$ in primigravida and $10 \%$ in nulliparous women. ${ }^{16}$ Rathee $\mathrm{S}$ et al, observed a higher incidence of severe anaemia in primipara than multipara being $28.33 \%$ and $17.76 \%$ respectively. ${ }^{17}$ Repeated and closely spaced pregnancies, prolonged period of lactation and poor dietary habits are responsible for depleted iron reserves in the body with each successive pregnancy and this reflects as severe anaemia and high perinatal mortality.

\section{Antenatal check-up}

Out of 225 cases of moderate anaemia only 50 cases $(22.22 \%)$ had antenatal check-up once twice. 175 $(77.77 \%)$ cases had no previous antenatal check-up. Out of 50 cases of moderate anaemia who had antenatal visit perinatal mortality was $6 \%$ while in 175 cases who had no antenatal visit perinatal mortality was $17.14 \%$. Out of 100 cases of severe anaemia, $90 \%$ had no previous antenatal visit and $10 \%$ had one or two antenatal visits. Perinatal mortality was $20 \%$ in cases who had previous antenatal visit and $41.11 \%$ in cases who had no previous antenatal visit. Dasgupta $\mathrm{S}$ et al, reported that severe anaemia accounted $13 \%$ of perinatal mortality about $85.9 \%$ of mothers did not receive adequate antenatal care services.

\section{Geographic distribution}

Out of 225 cases of moderate anaemia, $66.66 \%$ cases were rural and $33.33 \%$ cases were of urban group. Perinatal mortality was $14.66 \%$ in rural group and $10.66 \%$ in urban group. In severe anaemia out of 100 cases, $75 \%$ were rural and $25 \%$ were urban. Perinatal mortality was $44 \%$ in rural and $36 \%$ in urban population. Devi NB et al, reported anaemia in $53.55 \%$ in rural and $46.45 \%$ in urban population. ${ }^{18}$ This is due to fact that diet in India is predominantly cereal based and iron absorption is very poor due to presence of iron inhibitors.

\section{Socioeconomic status}

Out of 325 cases of anaemia $61.53 \%$ cases were of low socioeconomic class, $30.76 \%$ cases were of lower middle and only $7.69 \%$ cases were of upper middle class. Perinatal mortality was $27 \%$ in low class, $16 \%$ in lower middle class and $12 \%$ in upper middle class. Rathee $\mathrm{S}$ et al, reported incidence of anaemia 94.11\% lower class. Rangnakar et al, observed severe anaemia (67\%) in lower class and $(9 \%)$ in upper middle class. ${ }^{19}$

\section{Educational status}

Out of 325 cases of anaemia $49.23 \%$ cases were illiterate, $30.76 \%$ cases had primary education. $12.30 \%$ cases had education up to VIII class and $7.69 \%$ cases had education up to graduation. Perinatal mortality was $30 \%$ in illiterate group as compared to $4 \%$ in literate or educated group. Rathee $\mathrm{S}$ et al, studied (35.29\%) illiterate, $51.76 \%$ had primary education, $11.76 \%$ had middle and $1.17 \%$ were matriculate.

\section{Type of anaemia}

Perinatal mortality was $17.5 \%$ in dimorphic, 25.55 in microcytic hypochromic, $17.14 \%$ in normocytic normochromic and $22.22 \%$ in normocytic hypochromic 
anaemia. Satyanarayan $\mathrm{M}$ et al, observed microcytic hypochromic anaemia (68\%), dimorphic anaemia (30\%) and megaloblastic anaemia (2\%). Sinha $\mathrm{M}$ et al, studied iron deficiency anaemia (65\%), dimorphic anaemia $(18.3 \%)$, haemolytic anaemia $(11.6 \%)$ and megaloblastic anaemia $(5 \%){ }^{20}$

\section{Fetal outcome}

Fetal outcome in present study was in form of premature $49.23 \%$ birth with $33.12 \%$ perinatal mortality. There was $21.53 \%$ of mature babies with normal birth weight with $7.14 \%$ perinatal mortality and $29.23 \%$ of mature with low birth weight babies with $14.73 \%$ perinatal mortality. Rangnakar AG et al, reported prematurity in severe anaemia $(82.4 \%)$ and LBW babies $(82.4 \%)$. Devi NB et al reported prematurity in $(47.87 \%)$ and $(12.77 \%)$ of mature with low birth weight babies. Nair $\mathrm{M}$ et al, reported low birth weight babies $(29.2 \%)$ in moderate anaemia and $(60 \%)$ in severe anaemia. Rathee $\mathrm{S}$ et al, observed low birth in $(61.75 \%)$ cases. Stephan G et al, reported preterm $0.5 \%$ and low birth weight $3.6 \%{ }^{21}$ This low occurrence of negative pregnancy outcome compared to other studies might have occurred due to loss to follow up and diabetes and pre-eclampsia were not included in study.

\section{CONCLUSION}

Maternal anaemia in pregnancy is associated with illiteracy, low socioeconomic status, multiparity, inadequate antenatal care and rural geographic area and play a significant role both in maternal and perinatal mortality. It has also been observed that severe anaemia was associated with high perinatal mortality. There is a need to educate and provide various health measures to rural illiterate and poor population so as to raise the health standard of villagers and thereby reduce the prevalence of anaemia and feto maternal morbidity and mortality. Knowledge about adverse effect of anaemia can be delivered through media, pamphlets and doctors will enable women to seek early antenatal check-ups. If adequate measures are taken to improve maternal nutrition status from early weeks of pregnancy and supplementation of essential factors can at least minimize the severity of anaemia and then it will help in reducing perinatal mortality.

Funding: No funding sources Conflict of interest: None declared

Ethical approval: The study was approved by the Institutional Ethics Committee

\section{REFERENCES}

1. Schwartz WJ, Thurnau GR. Iron deficiency anaemia in pregnancy. Clin Obstet Gynecol. 1995;38(3):44354.

2. Marhatta R. Study of anaemia in pregnancy and its outcome in Nepal Medical college teaching hospital,
Kathmandu, Nepal. Nepal Med Coll J. 2007;9(4):270-4.

3. Rajeshwari K, Behera AK. The study of incidence of maternal anaemia in various age groups of women going to labour in Orissa. Inter $\mathrm{J}$ Rec Trend Sci Technol. 2014;12(2):250-2.

4. Kalaivani K. Prevalence and consequences of anaemia in pregnancy. Ind $\mathrm{J}$ Med Res. 2009;130(5):627-33.

5. Sarin AR. Severe anaemia in pregnancy, recent experience. Int J Gyneocol Obstet. 1995;50 (Suppl 2):45-9.

6. Brabin L, Nicholas S, Gogate A, Gogate S, Karande A. A high prevalence of anaemia among women in Mumbai, India. Food Nutr Bull. 1998;19(3):205-9.

7. Gregory P, Taslim A, Peter J, Gerjan PJ, Khan AQ. Health status of the Pakistani population: a health profile and comparison with the United States. Am J Public Health. 2001;91(1):93-8.

8. Sangeetha VB, Pushpalatha S. Severe Maternal Anaemia and Neonatal outcome. Sch J App Med Sci. 2014:2(1c):303-9.

9. Nair M, Choudhary MK, Choudhary SS, Katoky SD, Sharma UC. Association between maternal anaemia and pregnancy outcome: a cohort study in Assam, India. BMJ Global Health. 2016;1:e000026.

10. Modok GC, Sikdar K. A clinical study of grandmultiparas. J Obstet Gynae Ind. 1980:603-608.

11. Al-Mehaisen L, Khader Y, Al-Kuran O, Abu-Issa F, Amarin Z1. Maternal anaemia in Rural Jordan: room for improvement. Anaemia. 2011;2011:1-7.

12. Lokare PO, Karanjekar VD, Gattani PL, Kulkarni AP. A study of prevalence of anaemia and sociodemographic factors associated with anaemia among pregnant women in Aurangabad city, India. Ann Nigeria Med. 2012;6(1):30-4.

13. Agarwal KN, Agarwal DK, Sharma A, Sharma K, Prasad KMC, Khetarpaul N, et al. Prevalence of anaemia in pregnancy and lactating women in India. Indian J Med Res. 2006;124(2):173-84.

14. Uday D, Maitra A, Joshi J, Gokral J. Ferritin and haemoglobin level in rural India women: Their response to oral iron and associated with pregnancy outcome. J Obstet Gynae India. 1991;41:146-52.

15. Dasgupta S, Saha I, Lahiri A, Mandal Ak. A study of perinatal mortality and associated maternal profile in medical college hospital. J India Med Asso. 1997;95(3):78-9.

16. Satyanarayan M, Alli R. Anaemia complicating pregnancy. J Obstet Gynae Ind. 1985;35(11):335-8.

17. Rathee S, Khosa A, Sharma N, Garg R. Pregnancy outcome in severe anaemia. J Obstet Gvnec India. 1987;37(4):478-80.

18. Devi NB, Varalaxmi B, Jyothirmayi T, Lahari N. Maternal outcome in pregnancy with severe anaemia: prospective study in a tertiary care hospital in Andhra Pradesh. J Dent Med Sci. 2015;14(4):6-10.

19. Rangnekar AG, Darbari R. Foetal outcome in anaemia during pregnancy. J Obstet Gynae Ind. 1993;43:172-6. 
20. Sinha M, Panigrahi I, Shukla J, Khanna A, Saxena A. Spectrum of anaemia in pregnant Indian women and importance of antenatal screening. Indian J Pathol Microbiol. 2015;49(3):373-5.

21. Stephan G, Mgongo M, Hashin TH, Katanga J, Pederson BS, Msuya SE. Anaemia in pregnancy: prevalence, risk, factors and adverse perinatal outcome in Northern Tanzania. Anaemia. 2018;2018:9.

Cite this article as: Khatana A, Verma S, Sehra RN, Yadav K. Moderate to severe maternal anaemia in pregnancy and its impact on perinatal outcome in tertiary care hospital. Int J Reprod Contracept Obstet Gynecol 2020;9:1487-92. 